\title{
Que país é este? (memória, política e cultura)
}

\author{
Letícia Malard I UFMG
}

Resumo: Partindo de propostas teóricas do pesquisador britânico John Barrell, leremos o poema "Que pais é este?", de Affonso Romano de Sant'Anna, como uma declaração discursiva de realidade comparada com outras declaraçôes discursivas suas contemporâneas ou não, para entendê-lo precisamente como discurso que corporifica um problema, não universal nem genérico, mas específico e histórico do pais "Brasil", especialmente do regime militar (1964-1985). Palavras-chave: Pais, Sant'Anna, ditadura, história, Barrell

\footnotetext{
A mania dos tutores dos povos é distribuir a liberdade, como caldo à portaria do convento; e a desgraça dos povos tutelados é receber a caldeirada como um favor dos amos, augustos e não augustos.

(Machado de Assis. Diário do Rio de Janeiro, 24 jan. 1865.)
}

Em 2010, o livro Que país é este? e outros poemas, de Affonso Romano de Sant'Anna, chega aos trinta anos. ${ }^{1}$ O poema de abertura, que dá título ao livro, primeiramente foi publicado com destaque no Jornal do Brasil do Rio de

1. SANT'ANNA. Que país é este? e outros poemas. Todas as citações da obra foram retiradas dessa edição. Na edição comemorativa dos 30 anos foi acrescentado "O Livro" ao título. 
Janeiro. Editada pela guerreira Civilização Brasileira, a obra surgiu num momento crucial da política e da cultura do País, em que discursos paradoxais se entrecruzavam, tanto no espaço sócio-político-cultural quanto no espaço literário propriamente dito.

Na trilha de J. Barrell, acreditamos que a tentativa de ler poemas retornando-os ao momento histórico em que foram escritos / publicados não pode ser tomada como esperança de recuperar as experiências "reais" a que eles se referem. Também os poemas não podem ser considerados com o objetivo de comparar representações com a realidade que eles representam. Afinal, a recuperação do passado num poema constitui-se em outras representações desse passado: outros textos, outros discursos, ou outros exemplos de discursos incrustados no texto-objeto de análise.

Mas, se nós podemos comparar um poema, bem como um relato discursivo de realidade, com outros relatos discursivos dele contemporâneos literários ou não -, podemos começar a entendê-lo com propriedade: como discurso, como a corporificação de uma concepção parcial do mundo em competição com outras concepções parciais, como político, e não como universal. ${ }^{2}$

Abrindo parênteses: autores desavisados muitas vezes se sentem envaidecidos quando certa crítica avalia seus textos como "universais". Nada é mais falacioso, em que pese a utilização da categoria por críticos canônicos. O que seria um texto "universal"? Afirmar que Joyce, Guimarães Rosa e Proust, por exemplo, são "universais" é, além de inadequado, incorreto. Se for universal um texto que bem fala de liberdade, memória, sofrimento, morte, amor, guerras mundiais - então quase todos os textos literários ou pretensamente literários são universais. Se for universal um escritor contemporâneo traduzido e lido em dezenas de países García Márquez e Paulo Coelho, digamos - então, sim, há universalidade. Se for universal um ganhador de Prêmio Nobel, José Saramago, em nossa opinião o mais português e político dos escritores lusos, o qualificativo se aplica, apesar de ser ele "muito português". Mas aqui não estamos falando de mercado nem de láureas, mas de configurações literárias em si mesmas. Fechemos os parênteses.

Um texto literário alegadamente "universal" na verdade está enclausurado num patamar discursivo político que o "desuniversaliza" - quer por critérios crítico-analíticos, quer por espectros mercadológicos ou de lauréis. Assim,

2. BARRELL. Poetry, language and politics, p. 12. 
optamos por ler Que país é este? - tanto o poema quanto o livro - segundo John Barrell: não como relato de uma generalizada e universal afirmação sobre emoções humanas planetárias - depressão ou desapontamento - mas como declaração sobre um problema específico e histórico. ${ }^{3}$

Esse problema é a desconstrução identitária de "país" / de "pátria", numa situação histórica em que o poder constituído procurava, simultaneamente, reconstruir e destruir essa identidade. E mais: essa situação histórica estende ramificações para outros tempos e espaços, como um baobá gigante. Ressalte-se que a fonte de vários fatos aqui referidos é apenas nossa memória, como testemunha deles. Assim, nossa retomada do livro de Affonso, enquanto discurso comparado com um acervo de discursos, acaba sendo feita através de um método proustiano de revivência das perdas de nossa geração - minha e do poeta. Diz Proust:

$\mathrm{Na}$ realidade, cada leitor é, quando lê, o próprio leitor de si mesmo. A obra do escritor não é mais do que uma espécie de instrumento ótico que ele oferece ao leitor a fim de lhe permitir discernir aquilo que, sem tal livro, ele talvez não visse em si mesmo. O reconhecimento de si mesmo, pelo leitor, daquilo que diz o livro, é a prova da verdade do livro, e vice-versa, ao menos em certa medida, a diferença entre os dois textos podendo ser muitas vezes imputada não ao autor, mas ao leitor. ${ }^{4}$

Aí está a cara da moeda. A coroa é a utopia política do poeta / minha, seus projetos de uma comunidade ideal que ele não sabe qual é, mas sabe que não pode ser como até então tinha / tem sido, durante 500 anos. Para efeitos operacionais, conceituamos "utopia" seguindo J. Rancière: "não é o lugar que não está em parte alguma, mas o poder de recuperação entre um espaço discursivo e um espaço territorial; a identificação de um espaço perceptivo que se descobre ao andar no topos da comunidade." É por aí que caminham e que se encaminham o poema-título e outros poemas do livro.

Recortemos inicialmente os discursos da realidade de entorno a Que país é este?. João Batista Figueiredo - o último general-presidente da ditadura fora empossado em 13 de março de 1979, prometendo a redemocratização do Brasil. Efetivamente, envia em junho ao Congresso Nacional o projeto de anistia

3. BARrell. Poetry, language and politics, p. 12.

4. PROUST. A la recherche du temps perdu, t. III, p. 911. [Tradução minha.]

5. RANCIÈRE. Políticas da escrita, p. 114. 
aos perseguidos e perseguidores políticos, que foi aprovado em agosto. O temido Ato Institucional no 5 (AI-5) e outras leis de exceção, bem como os dois únicos partidos políticos desde 64 - Aliança Renovadora Nacional (ARENA) e Movimento Democrático Brasileiro (MDB) - foram extintos. Da clandestinidade, o Partido Comunista do Brasil (PC do B) conseguiu divulgar um manifesto à nação, condenando a usurpação da presidência da república por mais um general. Vários exilados retornam: o líder trabalhista Leonel Brizola, os comunistas Miguel Arrais, João Amazonas e Gregório Bezerra, e o idealizador das Ligas Camponesas - Francisco Julião.

Em meio a esse discurso prioritário de tentativas governamentais de recuperar o perdido, o novo livro de Sant'Anna vai receber a última demão para ser publicado. Os poemas não trazem datas, mas de qualquer modo não se deixam contaminar, na produção ou em retoques, por esses primeiros indícios de abertura política. Manifestam-se num processo contrário, típico de recalcamento, na contramão do discurso oficial bem como daquele que a ele se contrapunha - o manifesto comunista, no caso.

Dessa forma, a temática de Que país é este? e outros poemas se estabelece nel mezzo del camin de um país que vinha tropicando do seu passado mais remoto, estacionava em réplicas dos seus tropeços no presente e não parecia abrir-se, a curto prazo, para outros futuros. Ou, nas palavras de Moacyr Félix, orelhista da obra: o poeta "revela e costura, enfim, as relações existentes entre um tempo e outro, entre o distante e o próximo, entre o histórico e o estórico.” Porém, acrescentamos, o livro não se deixa contaminar pelas concessões do General nem engrossa o coro daqueles que o atacam ou o vaiam. ${ }^{6}$ O projeto poético de Sant'Anna é de outra natureza que não mero reprodutor do discurso do real, ao contrário de tantos outros textos literários seus contemporâneos.

Assim, por um lado anunciava-se na sociedade uma distensão em termos políticos; mas, por outro lado, aguçavam-se outras questões, que Affonso representava em sua poesia, numa corajosa perspectiva de "denúncia social", para usar uma expressão de época, não escorregando no panfletarismo nem na reprodução do real sem as necessárias mediações.

6. Em novembro de 1979 o ditador vai a Florianópolis e é recebido com vaias, numa manifestação organizada por estudantes. Sete universitários foram presos e enquadrados na temida Lei de Segurança Nacional. O material da TV Cultura, que cobria o evento, foi apreendido. Parece ter sido a primeira vez que um dirigente máximo do pós-64 foi coletivamente vaiado. O episódio ficou conhecido como "Novembrada". 
Vejam-se exemplos dessas questões, ilustrados com versos de poemas que as tematizam e que colocamos entre colchetes: a insegurança urbana ["Minha porta já tem 100 trincos"]; a violência contra a mulher ["e acompanhamos pasmos o enterro das vizinhas."]; a agressão ao meio ambiente ["Dizem: - pesca da baleia - como se dissessem: - jogar tênis"]; a crescente favelização ["panos furados de bala e bicho"] e a eterna submissão do índio ["carregando as armas do invasor"].

Vistos numa perspectiva de hoje, tais temas são inofensivos. Porém, nos anos do pós-64, de censura brava, quando reinava a literatura formalista ou asséptica, qualquer deslize dessa natureza podia levar a cabeça do autor a prêmio. Assim, eram pouquíssimos os livros "políticos" que se lançavam. O Feliz Ano Novo, contos de Rubem Fonseca, publicação apreendida em 1976 sob a acusação de incitar a violência, em princípios de 79 ainda era alvo de campanha por sua liberação.

Em 1980, esse livro de Affonso Romano arrematava um sexteto político "da hora", com cinco lançamentos em 78-79. O Que país é este?, de 78, da autoria de Millôr Fernandes, colocava-se na perspectiva do humorismo e da comicidade. O livro do guerrilheiro Marighella - Escritos de Carlos Marighella contém poemas sobre liberdade, feitos na prisão. O terceiro livro é o depoimento de Fernando Gabeira O que é isso, companheiro?, sobre o sequestro do embaixador norte-americano Elbrick, do qual participara. Gabeira também esteve exilado, trocado que foi pela liberdade do embaixador, e a ele Affonso dedica um poema do livro, "Canção do exílio mais recente". Completavam o sexteto as obras do casal esquerdista, personalidades mal vistas pela ditadura - Jorge-Zélia Amado: de Jorge - o romance Farda, fardão, camisola de dormir, tematizando a Academia Brasileira de Letras; de Zélia - as memórias Anarquistas, graças a Deus.

O texto satírico de Jorge narra as disputas entre fascistas e não fascistas por uma cadeira acadêmica. A Academia deixava-se cooptar naqueles anos de chumbo. Um de seus membros, eleito na década de 70, foi o general Aurélio de Lira Tavares, que, por duas vezes, durante a ditadura militar, integrou juntas governativas do País por alguns meses e foi autor ou co-autor dos temíveis Atos Institucionais. No ano da Semana de Arte Moderna, estudante do Colégio Militar do Rio de Janeiro, era diretor da revista literária Aspiração, onde escrevia poemas sob o pseudônimo de "Adelita" - sua sigla. ${ }^{8}$ O texto de Zélia Amado focaliza o

7. Sobre as questões de censura no período, veja-se: MALARD. Romance sob censura; e MALARD. Cultura e ditadura: um resgate de triste memória.

8. Cf.www2.gestao.presidencia.serpro.gov.br/.../pasta.2008-12-17. 1031375947 
Anarquismo em São Paulo no início do século XX, antissistema político que vários militares consideravam irmão do Comunismo. Como se não bastasse, o "graças a Deus" do título aparentava provocação.

Já em 1978, com o longo poema A grande fala do índio guarani perdido na História e outras derrotas, o poeta se colocava na linha de frente da poesia brasileira, não como soldado literário de uma guerra doméstica, mas de amplitude latino-americana, como apontou Tristão de Athayde: "longe de se situar nos 'subúrbios do Velho Mundo', [Affonso Romano de Sant'Anna] coloca-se em pleno continentalismo do Novo Mundo." No livro de 1980, Que país é este? e outros poemas, sem perder o seu caráter de "fecundo roteiro poético e crítico", divisado pelo mencionado papa da crítica literária erudita no livro anterior, o poeta vai reconhecer que o momento político brasileiro precisava da sua poesia, "numa reação contra a mediocridade e o conformismo", nas palavras de Athayde.

Vimos, em síntese, um quadro de 1979, quando se presume que o Que país é este? estava sendo ultimado, sem que o poeta soubesse ao certo qual futuro the estaria reservado ante a censura. A liberação ou proibição de vários livros para publicação eram creditadas a algum tipo de patronato, cremos que ainda não devidamente esclarecido: ou uns censores eram mais condescendentes do que outros, ou recebiam ordens aleatórias "de cima", ou liam e interpretavam a obra a seu bel-prazer, enfim: parece que não havia critérios confiáveis de objetividade. Mas, ao que se sabe, Affonso Romano não contava com padrinho algum para defender sua causa. ${ }^{10}$ Como se não bastasse, mandar um texto para a perseguida editora de Ênio Silveira, àquelas alturas, era um tiro na escuridão.

Vejamos agora os discursos políticos marcantes do ano 1980, a "fogueira" onde o livro se viu lançado. No campo cultural, a ditadura mordia e assoprava. De um lado, liberava peças e filmes antes censurados; de outro lado, apreendia jornais, como foi o caso d'O Pasquim, um periódico que detonava humoristicamente a ditadura. Entre as peças liberadas, Calabar: um elogio da traição, de Chico Buarque e Ruy Guerra. Entre os filmes, o grego $Z$, de Costa Gavras, sobre a perseguição e assassinato de um líder da oposição na Grécia. Ambos passavam recados explícitos para os ditadores.

\section{ATHAYDE. Poesia planetária.}

10. Não temos conhecimento de pesquisa no sentido de se descobrirem as razões pelas quais, durante aquele período, a censura liberava a publicação de alguns livros e de outros não, aparentemente sem critérios detectáveis, mas essa arbitrariedade era comentada com frequência. 
Também não foram criados problemas com a fundação do Grupo Gay da Bahia, nem com os shows da argentina revolucionária Mercedes Sosa e do jamaicano nada convencional Bob Marley, defensor dos pobres e dos oprimidos. Usuário e engajado na batalha pela descriminalização da maconha, assunto-tabu na época, o cantor de reggae e de crença rastafári deixou por cá muitos seguidores. Afinal, se essas visitas eram simplesmente toleradas pelo poder ditatorial, ficaram contrabalançadas com a do papa João Paulo II, primeiro pontífice a vir ao Brasil, tido como conservador apesar de polonês, e carreando multidões pelas cidades em que esteve.

Em contrapartida, no campo político stricto sensu, ações terroristas isoladas pipocavam em todo o território nacional, tanto de direita quanto de esquerda. Foram desativadas bombas no apartamento de Brizola, no Rio, e na Confederação Nacional de Agricultura, em Brasília. Bombas foram jogadas na redação do jornal Hora do Povo, de Porto Alegre, e na sede da Ordem dos Advogados do Brasil (OAB) do Rio. A sede paulista do Partido dos Trabalhadores (PT), fundado naquele ano, foi alvejada por tiros. Sequestraram o jurista Dalmo Dallari, ligado às esquerdas.

Ações públicas de rebeldia, até mesmo curiosas, eram noticiadas: em Pernambuco, o padre italiano Miracapillo se recusou a celebrar a "Missa da Independência" e foi expulso do País. As primeiras greves significativas pósgolpe tinham acontecido em 79 , abrindo caminho para outras tantas em 80 , como a segunda dos metalúrgicos do $\mathrm{ABC}$ paulista, que levou Lula à prisão por mais de um mês, e a dos professores do Estado Minas Gerais, reprimida com fortes jatos d'água.

Tais eram os flashes discursivos que, naquelas duas décadas, espoucavam no país real, país-pergunta de Sant'Anna. Expert do trabalho com a categoria "tempo" desde a sua tese de doutorado sobre o tempo em Drummond, ${ }^{11}$ ele sabe que, em termos de temporalidade, não há como concertar os desconcertos do mundo / do Brasil. Assim como a interpretação do fato não muda o fato, assim também o tempo não tem retorno para o exilado, o fuzilado, o desesperado, seus respectivos familiares e amigos. Anistias, voltas de exílio, revogação de leis, afrouxamento da censura, visita do papa, etc., não repõem nem perdoam nada.

11. SANT'ANNA. Drummond: o gauche no tempo (1972). Em edições posteriores, trocou-se o título do livro para Carlos Drummond de Andrade: análise da obra. 
Daí, a ideia de geração perdida, ironizada no mundo sacralizado, já que um dos antecedentes do Golpe Militar foi a Marcha do Terço, nas Minas do poeta: ${ }^{12}$

Minha geração se fez de terços e rosários:

$$
\begin{aligned}
& \text { - um terço se exilou } \\
& \text { - um terço se fuzilou } \\
& \text { - um terço se desesperou }
\end{aligned}
$$

Daí, também, o poeta, apesar de superinformado na condição de jornalista atuante, não mediar nos poemas fatos indiciadores da abertura política, pois, a bem da verdade, os discursos ditos redemocratizantes eram configurados no varejo e ele percebia que tudo "permanecia como dantes, no quartel de Abrantes". E mais: o desconcerto secular da Nação faz par com o desconcerto de sua geração, aos 40 anos, como se lê no poema "Uma geração vai, outra geração vem”, em que a descrença numa efetiva estabilidade política é sua causa e consequência. Afinal, boa parte dos regimes políticos latino-americanos oscilava entre democracia e ditadura, não raro com democracias durando só alguns meses. Então, para o poeta, ao invés da esperança na futura democracia, a certeza do eterno retorno:

Quando vier de novo a nova ditadura

estarei velho

e com tédio frente ao espelho

Fiquemos, a partir daqui, apenas no carro abre-alas do livro, o poema "Que país é este?". Com 14 páginas, está dividido em 7 partes, que corremos o risco de sumarizar, pois não se trata de um poema narrativo. Na primeira parte, $\mathrm{o}$ poeta especula sobre o que é / não é um país, saindo à procura do que dele restou no tempo. Na segunda, demonstra como durante 500 anos o país cultiva a repetição

12. A Marcha do Terço, realizada em fevereiro de 1964, em Belo Horizonte, foi preparada por padres e por várias organizações femininas. As pessoas, na maioria mulheres, saíram em passeata rezando o terço, dizendo-se estar lutando contra o comunismo. Condenaram Leonel Brizola como anticristo, pregaram a destituição do presidente João Goulart e pediram uma intervenção militar. Marchas semelhantes aconteceram no Rio de Janeiro e em São Paulo. 
do mesmo, do descontínuo, "onde nada congemina". Na terceira subdivisão, o poeta, conformista, aceita o país porque é o seu, o da sua infância. Na quarta, desenha-se a descrença no país, a partir dos acontecimentos presentes repercutindo o passado, e sem vislumbre de futuro. A quinta divisão corresponde ao país da geração perdida politicamente e seu canto fúnebre: os acomodados, os que pegaram em armas e se deram mal, fracassados que foram para a prisão, morte ou exílio. A sexta divisão é dedicada ao povo: as diversas categorias de povo, a desconfiança do povo em relação ao intelectual em seus complexos desacertos. A última seção lida com a ambiguidade do povo e a profissão do poeta; a fome do primeiro passa a ser prenúncio de revolução.

O título do livro pode ter correspondido a um somatório de fontes. A mais antiga que encontramos foi em Machado de Assis: numa discussão no Senado, um respeitável senador aparteou a outro com a frase "- Não caio nessa". Em sua crônica, o escritor indaga: "Em que tempo estamos? Que país é este? Pois um funcionário público, elevado às primeiras posições, - não para satisfação da vaidade, mas para servir ao país - responde daquele modo a uma intimação grave?" ${ }^{13}$ Não se sabe se os reprodutores da pergunta em textos anteriores ao de Sant'Anna o fizeram diretamente de Machado ou não, nem mesmo se Machado a teria apropriado de outrem. Já foi atribuída a seu antecessor José de Alencar, mas não conseguimos confirmar essa atribuição.

A utilização mais próxima da de Affonso - tanto na época quanto na seriedade do tema - foi a do roqueiro Renato Russo. Em 1978 ou 79, ele teria composto seu Que país é esse ( $\mathrm{sic}$, quando ainda era da banda brasiliense Aborto Elétrico. Trata-se de uma letra também política, que fala de corrupção, de desrespeito à Constituição, de venda da alma dos índios em leilão. Letra e música foram gravadas pela primeira vez somente em 1987, quando Russo já pertencia à banda Legião Urbana. Encontramos, também, informações de que o músico teria copiado o título de "um escritor", sem identificá-lo, e depoimentos de que às vezes Russo "copiava" coisas. No final dos anos 90 saiu mais um livro que traz por título a pergunta - o de João Sayad, sobre Economia.

Entretanto, a origem e a cronologia do título pouco importam. O que importa é registrar que, nessas diversas linguagens - crônica, letra de música,

13. Devo a José Américo de Miranda Barros a informação da existência de tal pergunta em Machado. Conseguimos localizá-la em ASsIS. Crônicas, v. 2, p. 96. Datada de 14 de agosto de 1864 . 
humorismo, poesia e ciências econômicas - temos concepções parciais do mundo em competição, como teoriza Barrell, todas enraizadas na mesma História brasileira. A pergunta - que Sant'Anna respondeu com grande vitalismo poético transbordou-se do não se sabe ao certo para discursos dialogantes de representações da cultura brasileira, e até hoje perpassa por novas representações discursivas gerando significados plurais. ${ }^{14}$

A título de curiosidade, vejamos algumas delas, sem incluir as geradas em blogues e livrarias, que são inumeráveis. No Centro Cultural da Juventude Ruth Cardoso, é uma atividade para se conhecerem outros países. No portal do Centro de Mídia Independente lê-se um pastiche anônimo do poema. Numa notícia da crise envolvendo o Equador e a construtora brasileira Odebrecht, apareceu a pergunta, relacionada àquele país, em tom de ironia. Nessa mesma linha, a notícia do sequestro e maus tratos de uma idosa e seu filho, mas nesse caso o país é Portugal. Em crítica ao Brasil, por não ter assinado o acordo sobre a proibição de bombas de dispersão, informando que outros países também não assinaram, inclusive os Estados Unidos e a Rússia. A estes últimos a pergunta não é dirigida.

Curioso, também, foi o próprio poeta ter escrito, para o Correio Braziliense, um artigo a respeito de sua demissão de presidente da Fundação Biblioteca Nacional, em junho de 96, por ter criticado a penúria financeira em que vivia a Biblioteca, quando o Ministro da Cultura era Francisco Weffort. O título do artigo: "Que ministro é esse?". Tal título hoje gera 40.300 resultados na pesquisa no Google. Pelo visto, depreende-se que a pergunta se aplica às mais diversas manifestações do campo social e cultural, com variadas intencionalidades e objetivos e, mais de um século depois de aparecida, é lembrada com sentido literal, ou metafórico em conotações de questionamento, revolta, perplexidade, ironia, irritação, desafio e similares.

Ultrapassada a questão do título, analisemos como o autor começa por incorporar a seu poema certos discursos culturais individualizados e disseminados no contexto do poema. Este é dedicado a Raymundo Faoro, o respeitado jurista e cientista político weberiano, autor de Os donos do poder: formação do patronato político brasileiro, e de Machado de Assis: a pirâmide e o trapézio. Ambas as obras, em segunda edição ampliada na década de 70 , rapidamente se tornaram

14. Em 19 de março de 2010, digitando-se a pergunta - com e sem o ponto de interrogação - na máquina de busca Google, apareceram aproximadamente 73.800 resultados. 
leitura obrigatória de grande parte da intelligentsia brasileira. Os donos do poder defendia a tese de que o estado patrimonialista no Brasil vinha do período colonial como herança do absolutismo português. Machado de Assis: a pirâmide e o trapézio questionava algumas posições sócio-políticas na literatura do grande escritor do século XIX, às quais um professor titular de Literatura Brasileira, como é Affonso, não poderia ficar indiferente.

É possível que, para o leitor ligado a questões políticas, o chamativo do primeiro livro de Faoro fosse mais devido ao título (os donos do poder $=$ os generais) do que propriamente a seus conceitos, sobressaindo-se aí o de "estamento burocrático". Este era conceituado como o exercício do poder em causa própria, com o objetivo de dominar a máquina política e administrativa do país. No caso em pauta, sob a alegação de livrar o território nacional do Comunismo - sistema político odiado e temido pelos militares, por grande parte da população religiosa e pelos conservadores.

Faoro combatia todas as formas de autoritarismo, que, segundo Simon Schwartzman, perdeu muito de seu apelo e sua atualidade, mas teve o seu momento e o seu papel nos anos 70-80. ${ }^{16}$ Schwartzman escrevia essa avaliação em 2003, mas hoje, sete anos depois, na opinião pelo menos de boa parte da mídia e dos políticos de oposição, este país vive um surto de autoritarismo. Sob tal aspecto, a obra faoriana se vê no topo da atualidade.

A abertura do poema joga, em suas rimas, com o vocábulo "estamento", sem utilizá-lo, e em vários de seus versos subjaz a leitura recente, pelo poeta, do livro de Faoro, além de novas rimas em "-mento":

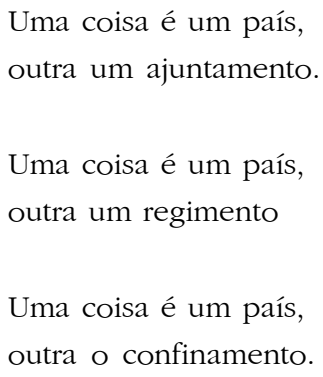

15. Sobre as questões polêmicas em Machado de Assis: a pirâmide e o trapézio, ver: MALARD. Balanço de um crítico, p. 3-6.

16. SCHWARTZMAn. Atualidade de Raymundo Faoro, p. 213. 
Mais adiante, a caracterização dos operadores do estamento:

homens gordos melosos sorrisos comensais

politicando subúrbios e arando votos

e benesses nos palanques oficiais.

Quanto ao Faoro analista e intérprete de Machado de Assis, não encontramos encarnação explícita no poema de Sant'Anna. Mas a evocação de Machado, num texto a respeito do país de 1861, se presentifica no país da poesia do poeta, quando este articula o país real - seu povo - com o país oficial, os governantes. Diz Machado:

O país real, esse é bom, revela os melhores instintos; mas o país oficial, esse é caricato e burlesco. A sátira de Swift nas suas engenhosas viagens cabe-nos perfeitamente. No que respeita à política nada temos a invejar ao reino de Lilipute. ${ }^{17}$

Afirma Sant'Anna, numa articulação entre o país real e o país oficial, transpondo a observação de Machado para mais de cem anos depois de feita, reforçando mais uma vez a repetição do mesmo nos discursos sobre a nação porque esta continuava sua tradição de 500 anos:

E enquanto ardíamos a derrota como escória

e os vencedores nos palácios espocavam suas champanhes sobre a aurora

o reprovado aluno aprendia com quantos paus se faz a derrisória estória.

A parte 3 do poema também dialoga com versos do poema "Prelúdio", de Falenas, segundo livro de poesia de Machado de Assis (1870), quando ambos os poetas, por comparações, preferem sua pátria devido a qualidades afetivas. Em Machado:

17. ASSIS. Crônicas, v.1, p. 111. 
A outra terra era má, o meu país é este;

Este o meu céu azul.

Se um dia padeceste

Aquela dor profunda, aquele ansiar sem termo

Que leva o tédio e a morte ao coração enfermo;

Se queres mão que enxugue as lágrimas austeras,

Se te apraz ir viver de eternas primaveras,

Ó alma de poeta, ó alma de harmonia,

Volve às terras da musa, às terras da poesia!

Em Sant'Anna:

Esta é a rua em que brinquei,

a bola de meia que chutei,

a cabra-cega que encontrei,

o passa-anel que repassei,

a carniça que pulei.

Este é o país que pude

que me deram

e ao que me dei,

e é possível que por ele, imerecido,

- ainda me morrerei.

No mesmo campo histórico-sociológico Affonso capta, não mais em dedicatória, porém dentro do poema, para fazer par com Faoro, outro clássico da cultura brasileira: Sérgio Buarque de Holanda e seu Visão do paraíso. A obra trata das representações do descobrimento e da colonização da América / do Brasil, enquanto Éden bíblico, nas narrativas do século XV ao XVIII. A diferença é que o poeta traz à baila essas representações, porém invertidas, degradadas e degredadas, "procurando [...] a viciosa visão do paraíso" extensiva ao século XX. Assim, os 500 anos do país não são edênicos, mas infernais: de caça aos oprimidos, de destruição da natureza, de intolerância religiosa, de estupros reais e metafóricos, de exploração generalizada.

Seguindo-se à dedicatória a Faoro, vem a epígrafe do poeta peruano César Vallejo. Este entrara para a vanguarda com o livro Trilce (1922), um título com neologismo misterioso, de onde foi retirada a epígrafe (poema LVII - que

18. ASSIS. Poesias completas, p. 194. 
Affonso não registra). Esse livro, publicado na gráfica da penitenciária de Lima, onde o poeta esteve preso, transportava a linguagem ao máximo da radicalidade e da experimentação, em apologia à liberdade como um valor em si.

Propagava a Liberdade não só da criação literária, mas também em todos os campos da vida, inclusive a de "absorver a pena em heroína", pena enquanto instrumento da escrita, conforme declara Vallejo na estrofe anterior à da mencionada epígrafe. Esse verso seria incitável, podendo ser Affonso acusado de propagandear o uso de drogas. Afinal, como já foi dito, ele desconhecia o tamanho das labaredas - reais e metafóricas - em que o livro seria consumido. A estrofe escolhida por Affonso fala de paradoxos: não traição, não bondade, boa vontade e autenticidade - tal como ele vai demonstrar no país do seu poema.

Evocando o Raymundo Faoro de Os donos do poder e do Machado de Assis: a pirâmide e o trapézio, e citando o Vallejo de Trilce, publicado no mesmo ano do The waste land, de Eliot, e da Semana de Arte Moderna, Affonso anuncia como irá trabalhar nas veredas tropicais do seu poema, tanto no que diz respeito à temática quanto à linguagem. No tema - a situação desconjuntada de um país historicamente patrimonialista e estamentado, as oposições entre o país real e o oficial, o eu lírico da infância, da juventude e da maturidade equilibrandose nesses dois países opostos, o anseio de liberdade poética e política, e o compromisso de desmascarar a terra definitivamente arrasada / desolada a partir de "April is the cruellest month" - primeiro verso de The waste land, mês em que se desencadeou o Golpe Militar. Assim Affonso metaforiza o Golpe, substituindo "cruellest" por "verde" - cor da farda dos militares, e não da esperança com seus olhos verdes:

Mas nem sempre ao verde abril

$$
\text { se segue a flor de maio. }
$$

Às vezes se segue o fosso

$$
\text { - e o roer do magro osso. }
$$

No que diz respeito à linguagem, um close-reading - que não é nossa intenção fazer aqui - vai revelar o poeta retirando o máximo de rentabilidade de recursos retóricos, tanto tradicionais quanto modernistas, adequando o discurso literário ao antigo e ao moderno, ao ontem e ao hoje poetizados em "Que país é este?". Do ponto de vista da configuração estrutural do poema, versos de diferentes extensões - ritmados e rimados se alternando com versos livres e versos brancos -, a irregularidade da estrofação e a distribuição 
espalhada das palavras na folha impressa indiciam o diálogo entre o modernismo, o pós-modernismo e as outras épocas, muito em acordo com a cobertura panorâmica dos 500 anos de Brasil e a inserção, na poesia, da personalidade histórica do poeta, então com cerca de 40 anos de idade, conforme vimos. Sobre sua história pessoal, diz ele, em outro poema-complemento deste:

Hoje, minhas filhas me perguntam

sobre esses quinze anos de outra ditadura

que me sobreveio em plena juventude

e eu as olho como um adulto olha o desamparo da criança.

("Uma geração vai, outra geração vem")

Em "Que país é este?", as repetições anafóricas imprimem um tom bíblico, ao mesmo tempo genesístico e apocalítico, respectivamente de construção e destruição:

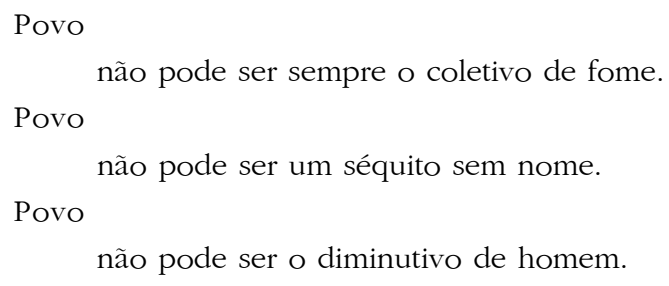

Essa materialidade da estrutura, em especial na utilização da rima e da anáfora, também serve de alavancagem da característica declamatório-dramática do poema e seu caráter explosivo, tal como as bombas de um dos discursos solapadores do governo Figueiredo. Nessa configuração original do poema, que inclui o aspecto visual da palavra impressa, Affonso parece incorporar de certa forma o campo literário (na acepção de Bourdieu) ${ }^{19}$ maiacovskiano, o do poema "Conversa sobre Poesia com o inspetor de impostos da Literatura", onde escreve o poeta russo:

19. Cf. BOURDIEU. As regras da arte: gênese e estrutura do campo literário. 
A rima

$$
\text { é um barril, }
$$

um barril com dinamite.

A estrofe é a mecha.

Acesa a estrofe,

explode...

e voa a estrofe

pelos ares da cidade.

Onde se encontram

e a que tarifa

rimas que apontem

e de um golpe matem?

a rima do poeta

é carícia

palavra de ordem,

látego

e baioneta. ${ }^{20}$

Por último, apontemos uma questão paralela à materialidade da estrutura, que é a materialidade da linguagem. Uma das inflexões originais do poema é a marcação da diferença entre o poeta e o povo, a sofisticação do discurso do poeta contrapondo-se ao discurso popular. Exemplificando: enquanto o poeta, na parte 1, se insere totalmente na cultura intelectual de pesquisador humanista da História / da Literatura, lendo jornais e anais, trabalhando na Torre do Tombo, de Lisboa, e nos arquivos nacionais para verificar "o que se salvou com o tempo", na parte 2 sua dicção dá lugar à voz do povo. A disparidade entre ambos os discursos é representada por uma sequência de versos que são provérbios, ditos e frases feitas populares - encenando um acervo de 500 anos de religiosidade conformista, de indiferença e consequente despaisamento (para usar o termo de Vattimo) ${ }^{21}$ político-social daqueles a quem não foi dado o direito de cidadania:

20. MAIACOVSKI. Antologia poética, p. 191 e p. 195.

21. VAтTimo. A sociedade transparente, p. 70. 
Há 500 anos dizemos:

que o futuro a Deus pertence, que Deus nasceu na Bahia, que São Jorge é que é guerreiro, que do amanhã ninguém sabe, que conosco ninguém pode, que quem não pode sacode.

Estamos diante de uma distinção de classe, sua fratura exposta na linguagem, ou, nas palavras de Haslett: "isso nos faz lembrar que, na sociedade capitalista, "versos" se tornou sinônimo de "versus", que a linguagem da poesia é, em última instância, um gosto exclusivista e elitizado e que nossas divisões sociais são mais evidentes e profundas na própria linguagem que falamos." ${ }^{22}$ O coroamento disso se explicita mais adiante, o fosso que separa "versos" e "versus":

Povo. Como cicatrizar nas faces sua imagem perversa e una?

Desconfio muito do povo. O povo, com razão,

- desconfia muito de mim.

Concluímos com uma boa lembrança: no ano da publicação do livro Que país é este? e outros poemas, declarou o crítico Wilson Martins - outro nome respeitável da intelligentsia brasileira e recentemente falecido - referindo-se a Affonso Romano de Sant'Anna:

[...] não pode haver nenhuma dúvida: ele é não só um poeta do nosso tempo, integrado nos seus problemas e perplexidades, nas incertezas sucessivas em que as certezas se resolvem, mas é também o grande poeta brasileiro que obscuramente esperávamos para a sucessão de Carlos Drummond de Andrade. ${ }^{23}$

Março de 2010.

22. HASLETT. Marxist literary and cultural theories, p. 46. [Tradução minha.]

23. MARTINS. Poeta do nosso tempo, p. 4. 


\title{
Que país é este? (memory, politics and culture)
}

\begin{abstract}
Supported by John Barrell's theoretical proposals, I will read Affonso Romano de Sant'Anna's poem "Que pais é este?" (What country is this?) as a discursive statement of reality, compared with other kinds of discursive statements, contemporary or not, to understand it precisely as discourse that embodies a problem, not a universal or general one, but a specific and historic discourse from the country "Brazil", in particular the military regime (1964-1985). Keywords: Country, Sant'Anna, dictatorship, history, Barrell.
\end{abstract}

$$
\text { Referências }
$$

AMADO, Jorge. Farda, fardão, camisola de dormir. Rio de Janeiro: Ed. Record, s.d. ASSIS, Machado de. Crônicas. Rio de Janeiro-São Paulo-Porto Alegre: W. M. Jackson, 1942. v. 1

ASSIS, Machado de. Crônicas. Rio de Janeiro-São Paulo-Porto Alegre: W. M. Jackson, 1944. v. 2

ASSIS, Machado de. Poesias completas. Rio de Janeiro-São Paulo-Porto Alegre: W. M. Jackson, 1944.

ATHAYDE, Tristão de. Poesia planetária. Estado de Minas, C, Belo Horizonte, 7 abr. 1979. p. 2 .

BARRELL, John. Poetry, language and politics. Manchester: Manchester University Press, 1991.

BOURDIEU, Pierre. As regras da arte: gênese e estrutura do campo literário. São Paulo: Compannia das Letras, 1996.

BUARQUE, Chico; GUERRA, Ruy. Calabar: o elogio da traição. Rio de Janeiro: Civilização Brasileira, 1973.

ELIOT, T. S. The waste land. Criterion, London, oct. 1922.

FAORO, Raymundo. Machado de Assis: a pirâmide e o trapézio. São Paulo: Ed. Nacional, 1974.

FAORO, Raymundo. Os donos do poder: formação do patronato político brasileiro. 2. ed. rev. e aum. Porto Alegre-São Paulo: Ed. Globo / Ed. Universidade de São Paulo, 1975. 2 v.

FERNANDES, Millôr. Que país é este? Rio de Janeiro: Círculo do Livro, 1978.

GABEIRA, Fernando. O que é isso, companheiro? Rio [de Janeiro]: Ed. Codecri, 1980. GATTAI, Zélia. Anarquistas graças a Deus. Rio de Janeiro: Ed. Record, 1979.

HASLETT, Moyra. Marxist literary and cultural theories. New York: St. Martin's Press, 2000 . 
HOLLANDA, Sérgio Buarque de. Visão do paraíso. São Paulo: 1959 (tese de cátedra). MAIACOVSKI, Vladímir. Antologia poética. Trad. E. Carrera Guerra. Rio de Janeiro: Ed. Leitura, s.d.

MALARD, Letícia. Balanço de um crítico. Minas Gerais: Suplemento Literário, Belo Horizonte, a. 37, n. 1263, 1 de junho de 2003, p. 3-6.

MALARD, Letícia. Cultura e ditadura: um resgate de triste memória. In: Literatura e dissidência política. Belo Horizonte: Ed. UFMG, 2006. p. 33-47.

MALARD, Letícia. Romance sob censura. O Eixo e a Roda, v. 5, nov. 1986, p. 70-86.

MARIGHELlA, Carlos. Escritos de Carlos Marighella. São Paulo: Ed. Livramento, 1979.

MARTINS, Wilson. Poeta do nosso tempo. Jornal do Brasil, Caderno B, Rio de Janeiro, 4 out. 1980.

PROUST, Marcel. A la recherche du temps perdu. Bruges: Ed. Gallimard, 1959. t. III.

RANCIÈre, Jacques. Políticas da escrita. Rio de Janeiro: Ed. 34, 1995.

RUSSO, Renato. Que país é esse. Disponível em www. letras.com.br/renato-russo/ que-pais-e-este

SANT'ANNA, Affonso Romano de. A grande fala do índio guarani perdido na história e outras derrotas: moderno Popol Vuh. São Paulo: Summus Ed., 1978.

SANT'ANNA, Affonso Romano de. Drummond, o gauche no tempo. Rio de Janeiro: Ed. Record, 1972

SANT'ANNA, Affonso Romano de. Que país é este? e outros poemas. Rio de Janeiro: Civilização Brasileira, 1980.

SAYAD, João. Que país é este. Rio de Janeiro: Ed. Revan, 1999.

SCHWARTZMAN, Simon. Atualidade de Raymundo Faoro. Dados, Revista de Ciências Sociais, Rio de Janeiro, v. 46, n.2, p. 207-213, 2003.

VALLEJO, César A. Trilce. Lima: Talleres de la Penitenciaría de Lima, 1922.

VATTIMO, Gianni. A sociedade transparente. Lisboa: Edições 70, 1991.

www2.gestao.presidencia.serpro.gov.br/.../pasta.2008-12-17.1031375947 [sobre Aurélio de Lira Tavares] 